DOI: $10.47743 /$ jss-2021-67-4-14

\title{
Perspective curente de semnare a contractelor online în dreptul comparat
}

\section{Current Perspectives for Online Contracts Signing in the Comparative Law}

\section{Andreea-Luminiţa Buţureanu-Cărpuşor ${ }^{1}$}

\begin{abstract}
Rezumat: Posibilitatea semnării contractelor în variantă electronică este o practică răspândită cu mult înainte de începutul pandemiei COVID-19 la nivel global şi continuă să faciliteze relaţiile dintre părţi, prestarea de servicii şi obţinerea de profituri. În ciuda posibilităţii de semnare frauduloasă a contractelor, încheierea online aduce beneficii importante în reducerea birocraţiei şi pentru relaţiile comerciale internaţionale. Lucrarea de faţă îşi propune să delimiteze specificul semnării contractelor online în România şi Marea Britanie. Scopul acestui demers comparativ este atât de a evidenţia oportunităţile oferite de legislaţia actuală, cât şi de a identifica potenţiale îmbunătăţiri legislative locale prin raportare la legislaţia britanică. În prima parte, discutăm despre legislaţia ţării noastre şi tipurile de contracte care se pretează semnării online. În partea a doua, problematizăm semnarea contractelor online în Marea Britanie.
\end{abstract}

Cuvinte-cheie: contractele online în România; contractele online în Marea Britanie; practica judiciară a contractelor online

Abstract: The possibility of signing contracts electronically is a widespread practice long before the onset of the global COVID-19 pandemic and continues to facilitate relations between the parties, the provision of services and the making of profits. Despite the possibility of fraudulent signing of contracts, online conclusion brings important benefits in reducing bureaucracy and for international trade relations. This paper aims to delimit the specifics of signing online contracts in Romania and the United Kingdom. The purpose of this comparative approach is both to highlight the opportunities offered by current legislation and to identify potential local legislative improvements in relation to British legislation. In the first part, we discuss the legislation of our country and the types of contracts that are suitable for signing online. In the second part, we question the signing of online contracts in the UK.

Keywords: online contracts in Romania; online contracts in the UK; judicial practice of online contracts

${ }^{1}$ Doctorand, Facultatea de Drept, Universitatea „Alexandru Ioan Cuza” din Iași, e-mail: bnpcarpusor2021@gmail.com. 


\section{Contractele online în România}

Contractul reprezintă înţelegerea formală şi scrisă dintre două părţi care are rolul de a consfinţi între acestea realitatea instituirii unor drepturi şi/sau obligaţii între acestea. Dintr-o perspectivă mai nuanţată, putem spune faptul că fiecare contract are rolul de a fi un reper în timp şi o piedică împotriva uitării drepturilor şi/sau responsabilităţilor care decurg din acesta - „verba volant, scripta manent”.

Utilizarea semnăturii electronice şi a contractelor online este susţinută de statul român prin următoarele reglementări: art. 1245 din Codul civil, art. 267 şi 268, alineatul 2) din Codul de procedură civilă din România, Legea nr. 455/2001 privind semnătura electronică, normele tehnice şi metodologice de aplicarea Legii nr. 455/2001 privind semnătura electronică, Legea nr. 451/2004 privind marca temporală, Ordinul MCSI nr. 492/2009 privind normele tehnice şi metodologice pentru aplicarea Legii nr. 451/2004 privind marca temporală, Legea nr. 135/2007 privind arhivarea documentelor în formă electronică, Ordinul MCSI nr. 493/2009 privind normele tehnice şi metodologice pentru aplicarea Legii nr. 135/2007 privind arhivarea documentelor în formă electronică, Ordonanţa de urgenţă a Guvernului nr. 34/2014 privind drepturile consumatorilor în ceea ce priveşte contractele la distanţă, Legea nr. 365/2002 privind contractele încheiate prin mijloace electronice şi Ordonanţa de Urgenţă nr. 36 din 5 mai 2021.

În prezent, următoarele tipuri de contracte deja fac obiectul semnării online, cu sau fără semnătură electronică calificată în practica românească: contractul de muncă (începând din anul 2018), de vânzare-cumpărare, contractul de credit, de antrepriză, de arendare, contractul de joc şi pariu. Pe baza semnăturii electronice simple sau calificate (de tip DocuSign sau certSIGN), şi contractele de locaţiune, de comodat şi de arendare pot fi semnate online, cu condiţia depunerii unei copii a contractului la primăria din raza locuinţei şi a bunurilor arendate. În egală măsură, opinăm că, dacă vânzarea şi prestarea de servicii pot face obiectul unor contracte semnate electronic, şi contractele de întreţinere, respectiv donaţie, se pot bucura de acelaşi regim.

În ciuda popularităţii sporite a semnăturii electronice calificate, Regulamentul UE eIDAS subliniază, printre altele, un aspect important, anume că un document electronic nu poate fi refuzat ca probă pe motiv că nu este semnat electronic calificat ${ }^{2}$.

Fiind un regulament al UE, eIDAS este obligatoriu şi se aplică direct în sistemul juridic naţional. eIDAS are prioritate faţă de Legea nr. 455/2001, şi oferă posibilităţi mai extinse faţă de aceasta. În orice caz, eIDAS se bazează pe principiul conform căruia efectul juridic al semnăturilor electronice este definit de legislaţia naţională, cu excepţia cerinţei conform căreia o semnătură electronică calificată ar trebui să aibă efectul juridic echivalent al unei semnături scrise de mână ${ }^{3}$.

2 Paragraful 63 din Regulamentul (UE) nr. 910/2014 al Parlamentului European și al Consiliului din 23 iulie 2014 privind identificarea electronică și serviciile de încredere pentru tranzacțiile electronice pe piața internă și de abrogare a Directivei 1999/93/CE.

${ }^{3}$ Paragraful 49 din preambulul eIDAS. 
În mod fundamental, semnătura electronică este definită ca un cumul de date în formă electronică care sunt ataşate sau asociate logic cu alte date în formă electronică şi care sunt utilizate de semnatar pentru a semna ${ }^{4}$. Sunt reglementate trei tipuri de semnături electronice:

-Semnătura electronică simplă - constă în date în formă electronică care sunt ataşate sau asociate logic cu alte date în formă electronică şi care sunt utilizate de semnatar pentru a semna. De pildă, semnătura utilizată într-un e-mail sau semnătura dată pe anumite tampoane digitale pentru semnături ${ }^{5}$.

-Semnătura electronică extinsă, denumită semnătură electronică avansată („AES”) în eIDAS - este semnătura electronică care: este legată în mod unic de semnatar, permite identificarea semnatarului, este creată folosind date de creare a semnăturii electronice pe care semnatarul le poate utiliza, cu un nivel ridicat de încredere, sub controlul său exclusiv; şi este legată de datele semnate cu acesta, astfel încât orice modificare ulterioară a datelor să fie detectabilắ

Semnătura electronică extinsă bazată pe un certificat calificat, denumită semnătură electronică calificată $(\mathrm{QES})$, este o semnătură electronică avansată creată de un dispozitiv de creare a semnăturii electronice calificate şi care se bazează pe un certificat calificat pentru semnături electronice.

Distincţia semnificativă dintre AES şi QES constă în faptul că aceasta din urmă este generată de un dispozitiv calificat de creare a semnăturilor electronice. Acest element suplimentar ale QES are rolul de a întări identitatea semnatarului, motivul pentru care QES este considerat cel mai sigur tip de semnătură electronică, cu o valoare legală superioară. Totuşi, aşa cum am precizat, lipsa unei semnături electronice calificate nu atrage după sine nulitatea unui contract online ${ }^{7}$. Este important de precizat că în ţara noastră contractele semnate online fac obiectul legislaţiei doar din perspectiva formării lor.

În practică, însă, contractului încheiat la distanţă nu îi sunt recunoscute pe deplin efectele. În ciuda faptului că un contract poate fi încheiat prin telefon sau pe internet, fără cerinţa unei semnături olografe sau electronice, în cazul unui litigiu, un contract astfel încheiat este privit ca unul deficitar. Recunoaşterea deplină a efectelor şi punerea în executare silită par uneori privilegii rezervate doar clasicelor contracte redate prin înscrisuri sub semnătura privată sau chiar autentice, singura concesie fiind cea în favoarea contractelor semnate prin semnătura electronică extinsă. Un exemplu elocvent în acest sens îl constituie practica neunitară a

${ }^{4}$ C. Constantinescu, Semnătura electronică - relații (comerciale) la distanță, Juridice.ro, 2020, [Online] la https://www.juridice.ro/680846/semnatura-electronica-relatii-comercialela-distanta.html, accesat 02.11.2021.

${ }^{5}$ Ș. Grigorescu, The electronic signature: long-distance (commercial) relationships, 2020 , Bpv-grigorescu.com, [Online] la https://www.bpv-grigorescu.com/news/the-electronicsignature-long-distance-commercial-relationships/, accesat 04.11.2021.

${ }^{6}$ Ibidem.

${ }^{7}$ CertSIGN, Semnătura electronică şi contractul la distanţă, în justiţie. Valide sau nu?, CertSIGN.ro, 2020, [Online] la https://www.certsign.ro/ro/semnatura-electronica-sicontractul-la-distanta-in-justitie/, accesat 05.11.2021. 
instanţelor de judecată în ceea ce priveşte caracterul de titlu executoriu al contractelor de servicii financiare încheiate la distanţă. Pe de o parte, au fost instanţe de judecată care au apreciat că un contract de credit încheiat cu respectarea prevederilor O.G. nr. 85/2004 privind protecţia consumatorilor la încheierea şi executarea contractelor la distanţă privind serviciile financiare poate constitui titlu executoriu chiar dacă el nu cuprinde semnătura olografă sau, după caz, semnătura electronică extinsă a debitorului. Pe de altă, au existat instanţe care au considerat că acele contracte de furnizare de servicii de credit încheiate la distanţă care nu conţin semnătura olografă sau, după caz, semnătura electronică extinsă a debitorului nu constituie titluri executorii ${ }^{8}$.

O recentă decizie a Înaltei Curţi de Casaţie şi Justiţie pronunţată într-un recurs în interesul legii (Decizia nr. 23/2019) tranşează această problemă aducând o schimbare clară de optică. Astfel, instanţa supremă a decis în favoarea recunoaşterii caracterului de titlu executoriu cu privire la contractele de servicii financiare încheiate la distanţă cu respectarea strictă a dispoziţiilor legale speciale, chiar în lipsa semnăturii olografe sau a semnăturii electronice extinse, cu excepţia situaţiei în care părţile impun semnătura drept condiţie de validitate a contractului ${ }^{9}$.

În susţinerea deciziei sale, Î.C.C.J. subliniază că, de vreme ce norma specială care reglementează încheierea contractelor la distanţă, respectiv O.G. nr. 85/2004, nu prevede nicio obligaţie în sarcina părţilor contractante de a semna convenţia încheiată, această condiţionare nu poate fi impusă suplimentar pentru a recunoaşte acestor contracte caracterul de titlu executoriu consacrat pentru contractele de credit prin art. 52 alin. (1) din Legea nr. 93/2009 şi art. 120 din O.U.G. nr. 99/2006 ${ }^{10}$.

Mai mult, Î.C.C.J. atrage atenţia că o astfel de condiţionare „ar fi chiar în contradicţie cu mecanismul încheierii contractelor la distanţă, inter absentes, precum şi cu specificul contractelor referitoare la servicii financiare, la comerţul electronic, bazat pe celeritate şi pe lipsa formalismului, contractele de acest gen ţinând de activitatea comercială şi fiind funciarmente contracte care se încheie solo consensu"11.

Prin aceeaşi decizie, instanţa supremă a statuat şi că un contract încheiat la distanţă, cu respectarea regulilor incidente, reprezintă un înscris pe suport informatic, mijloc de probă distinct şi se bucură de prezumţia de validitate a înscrierii şi de putere doveditoare în condiţiile Codului de procedură civilă ${ }^{12}$.

${ }^{8}$ A. Jivan, Contractul la un click distanță, Economica.net, 2013, [Online] la https://www.economica.net/contractul-la-un-click-distan-a-avoca-ii-explica-ce-riscuriaduc-contractele-electronice-foarte-utilizate-in-contextul-pandemiei-de-

coronavirus_183864.html, accesat 07.11.2021.

${ }^{9}$ Ibidem.

${ }^{10}$ Ibidem.

${ }^{11}$ Înalta Curte de Casație și Justiţie, Decizia nr. 23 din 14 octombrie 2019, publicată în Monitorul Oficial nr. 142 din 21 februarie 2020.

12 Ibidem. 
Putem concluzia că, deşi Decizia nr. 23/2019 reprezintă fără îndoială un pas înainte în sprijinul consolidării eficacităţii contractelor încheiate la distanţă, rămân, în continuare, de actualitate problemele legate de proba contractului încheiat la distanţă. Astfel, conform art. 282-283 din Codul de procedură civilă, un act juridic ale cărui date există iniţial doar pe suport informatic poate fi probat printr-un document care reproduce respectivele date doar dacă acel document este inteligibil şi prezintă garanţii suficient de serioase pentru a face deplină credinţă în privinţa conţinutului acestuia şi a identităţii persoanei de la care acesta emană. În ce constau acele garanţii, dacă sunt ele suficient de serioase - sunt aspecte ce rămân la aprecierea instanţei de judecată care va decide de la caz la caz, ţinând cont de circumstanţele în care datele au fost înscrise şi de documentul care le-a reprodus.

De asemenea, prezumţia de valabilitate a înscrierii menţionată în Decizia nr. 23/2019 este şi ea condiţionată de cerinţa ca înscrierea să fie făcută în mod sistematic şi fără lacune, iar datele înscrise să fie protejate contra alterărilor şi contrafacerilor astfel încât integritatea documentului să fie deplin asigurată ${ }^{13}$.

Prin urmare, în cadrul legal actual, jurisprudenţa are un rol esenţial în asigurarea eficacităţii contractelor încheiate la distanţă, instanţele fiind chemate să asigure un just echilibru între protecţia reală a intereselor părţilor, a consumatorilor în primul rând şi nevoia acceptării şi utilizării pe scară largă a contractelor încheiate în mediul virtual.

Până la consolidarea unei jurisprudenţa unitare care să ofere criterii clare, însă, în ciuda atitudinii încurajatoare a instanţei supreme, participanţii la comerţul online, şi în special profesioniştii, trebuie să fie conştienţi de riscurile pe care le implică încheierea contractelor la distanţă şi să ia masurile necesare pentru diminuarea acestora. Astfel, este de dorit ca profesioniştii să structureze cu atenţie procedurile de vânzare on-line, să aleagă cu grijă sistemele informatice pe care le folosesc şi să respecte întocmai normele legale speciale aplicabile în funcţie de tipul de produse sau servicii pe care le oferă ${ }^{14}$.

\section{Contractele online în Regatul Unit al Marii Britanii şi Irlandei de Nord}

În spaţiul britanic, cu excepţia contractelor care oferă posibilitatea transferului de drepturi privind proprietăţile imobiliare, toate categoriile de contracte pot face obiectul semnării online ${ }^{15}$, iar următoarele prevederi reglementează acest aspect:

${ }^{13}$ Ibidem.

${ }^{14}$ Ibidem.

${ }^{15}$ A. Ruwanthika, Protecting consumer rights in electronic contracts: a lesson from the European Union and the United Kingdom, 11th International Research Conference, General Sir John Kothalawala Defence University, September 13th -14th 2018, Conference Proceedings, 2018. [Online] la https://www.researchgate.net/publication/349552079 PROTECTING_CONSUMER_RIGHTS_IN_ELECTRONIC_CONTRACTS_A_LESSONS_FR OM_EUROPEAN_UNION_AND_UNITED_KINGDOM, accesat 02.11.2021. 
-Regulamentul privind comerţul electronic din 2002 (Regulamentul privind comerţul electronic) impune operatorilor de site-uri comerciale o serie de obligaţii, în special obligaţii de a furniza utilizatorilor anumite informaţii despre operator şi serviciile acestuia.

- Consumer Rights Act 2015 (CRA) a consolidat o serie de legislaţii anterioare din Marea Britanie privind drepturile consumatorilor şi a actualizat anumite domenii, inclusiv condiţiile legale implicite din contractele consumatorilor şi remediile pentru încălcări disponibile consumatorului.

- Regulamentul privind contractele de consum (informaţii, anulare şi taxe suplimentare) din 2013 (Regulamentul privind contractele de consum) impune obligaţii suplimentare operatorilor de site-uri web care se ocupă de consumatori, precum şi introducerea drepturilor de anulare pentru consumatori.

-Reglementările din 2008 privind protecţia consumatorilor împotriva tranzacţiilor neloiale (CPR) interzic diverse practici neloiale ale comercianţilor, precum acţiuni sau omisiuni înşelătoare şi includ o „listă neagră” de practici comerciale interzise.

- Regulamentul privind furnizarea de servicii din 2009 (regulamentele POS) prevede că, în furnizarea de servicii, comercianţii nu trebuie să facă discriminări între rezidenţii SEE pe motive de naţionalitate sau locul de reşedinţă, cu excepţia cazului în care este justificat de criterii obiective (de exemplu, furnizarea de servicii transfrontaliere implică anumite costuri adiţionale).

-GDPR şi Legea privind protecţia datelor 2018 (DPA) conţin prevederi referitoare la utilizarea datelor cu caracter personal, inclusiv cu privire la utilizatorii site-ului web.

- Regulamentele din 2003 privind confidenţialitatea şi comunicaţiile electronice (Directiva CE) din 2003 (Regulamentele PEC) reglementează marketingul direct (atât solicitat, cât şi nesolicitat) prin intermediul comunicării electronice.

Se poate observa faptul că, dincolo de formarea contractului, legislaţia britanică are în vedere mai multe aspecte privind contractele online, precum informarea şi protecţia consumatorilor, împreună cu practicile neloiale care pot apărea şi sunt desemnate o serie de instituţii pentru protecţia părţilor în cazul încălcării prevederilor care ţin de buna executare a contractelor.

Totodată, în spaţiul anglo-saxon, contractul de arendare face obiectul semnării online în mod explicit şi se specifică faptul că dacã arendatorul semneazã contractul de arendare şi îl expediazã arendaşului spre a fi semnat, se poate presupune cã arendaşul are la dispoziţie mai mult timp pentru a studia condiţiile contractuale, însă, în acelaşi timp, în această perioadă arendaşul poate abandona semnarea contractului. Aceastã situaţie ar prejudicia interesul arendatorului deoarece perioada de timp în care terenul sãu nu este fructificat se reflectã în 
pierderi de ordin financiar. Se impune, astfel, ca primul semnatar al contractului de arendare sã fie arendaşul ${ }^{16}$.

Pentru ca un contract online să aibă efecte, trebuie să existe o ofertă, acceptare, intenţia de a crea relaţii juridice şi certitudinea termenilor. Oferta, acceptarea şi încorporarea termenilor sunt de o importanţă deosebită atunci când se realizează contracte online.

Pentru a oferi comerciantului control asupra termenilor contractului, termenii şi condiţiile unui site web adesea afirmă că, prin trimiterea unei comenzi, clientul face o ofertă, şi descrie termenii în care se consideră că comerciantul a acceptat oferta respectivă, de exemplu, numai după ce a trimis clientului un e-mail de confirmare a comenzii.

Termenii contractului trebuie aduşi suficient la cunoştinţa clientului înainte de finalizarea contractului. Instanţele engleze nu au oferit îndrumări definitive cu privire la modul în care trebuie încorporaţi termenii şi condiţiile online, dar au evidenţiat faptul că cel mai eficient mod de a proiecta site-ul web este astfel încât clientul să nu poată finaliza comanda până când nu a derulat termenii şi condiţiile complete de pe ecran şi a făcut click pe un buton de „Accept” (sau similar). Acest lucru este cunoscut sub numele de contract click-wrap. În contextul acordurilor de licenţă software (cunoscute sub numele de acorduri de licenţă pentru utilizatorul final) există alte două forme comune de contract:

- Contracte browse-wrap, în care un utilizator este pur şi simplu notificat că, continuând să utilizeze software-ul, acesta va fi obligat de anumiţi termeni şi condiţii, dar fără ca acesta să fie nevoit să ia o acţiune pozitivă pentru a-i accepta.

- Contracte de reducere, în cazul în care un utilizator achiziţionează un produs software fizic şi termenii sunt fie incluşi în ambalaj, fie într-un fişier care trebuie să fie deschis în timpul instalării1 ${ }^{17}$.

\section{Concluzii}

Posibilităţile de semnare online a contractelor din România sunt, în prezent, mult mai variate decât se cunoaşte şi se anunţă a fi o practică mult mai răspândită în lumina regulamentului eIDAS. Reţinem faptul că, în ciuda popularităţii sporite a semnăturii electronice calificate, un aspect important este că un document electronic nu poate fi refuzat ca probă pe motiv că nu este semnat electronic calificat. Totodată, dacă legislaţia românească tinde să accentueze aspectele legate de formarea contractului în formă electronică, cea britanică detaliază atât tipurile de contracte online posibile, cât şi informarea şi protecţia consumatorilor, împreună cu practicile neloiale care pot apărea şi sunt desemnate o serie de instituţii pentru protecţia părţilor în cazul încălcării prevederilor care ţin de buna

${ }^{16}$ A.H. Adenuga, C. Jack, R. McCarry, The Case for Long-Term Land Leasing: A Review of the Empirical Literature, Land, Nr.10/ 2021, 238, [Online] la https://doi.org/10.3390/ land10030238, accesat 29.10.2021.

${ }^{17}$ E. McKendrick, L. Qiao, Contract Law, Ediția a 13-a, MacMillan Law, 2019, p. 82, Kindle edition. 
executare a contractelor. În viitorul apropiat, ar fi importantă reglementarea tuturor aspectelor legate de contractele online şi în legislaţia românească, în virtutea realităţilor pandemice.

\section{Referinţe}

Adenuga A.H., Jack C., McCarry R., The Case for Long-Term Land Leasing: A Review of the Empirical Literature, Land, Nr.10/ 2021, 238, https://doi.org/ 10.3390/land10030238

Constantinescu C., Semnătura electronică - relaţii (comerciale) la distanţă, Juridice.ro, 2020, [Online]

CertSIGN, Semnătura electronică şi contractul la distanță, în justiţie. Valide sau nu?, CertSIGN.ro, 2020, [Online]

Grigorescu Ş., The electronic signature: long-distance (commercial) relationships, 2020, Bpvgrigorescu.com, [Online]

Înalta Curte de Casaţie şi Justiţie, Decizia nr. 23 din 14 octombrie 2019, publicată în Monitorul Oficial nr. 142 din 21 februarie 2020

Jivan A., Contractul la un click distanţă, Economica.net, 2013, [Online]

McKendrick E., Qiao L., Contract Law, Ediţia a 13-a, MacMillan Law, 2019, Kindle edition

Puie O., Tratat de contracte civile potrivit Codului civil, Codului de procedură civilă, Codului fiscal, Codului de procedură fiscală, Codului penal şi Codului de procedură penală, Volumul I, Editura Universul Juridic, Bucureşti, 2018

Romoşan I.D., Obligaţii, Editura Universul Juridic, Bucureşti, 2018

Ruwanthika A., Protecting consumer rights in electronic contracts: a lesson from the European Union and the United Kingdom, 11th International Research Conference Proceedings, General Sir John Kothalawala Defence University, September 13th -14th 2018 